ON BEI 2013 - 2018)

\title{
PENGARUH KECUKUPAN MODAL, RISIKO KREDIT, PROFITABILITAS, DAN UKURAN BANK TERHADAP LIKUIDITAS (STUDI PADA PERUSAHAAN PERBANKAN YANG TERDAFTAR DI BEI TAHUN 2013 - 2018)
}

\author{
Oleh: \\ Marizha Dwi R ${ }^{1)}$, Sri Rahayu²), Ilham Wahyudi ${ }^{3)}$ \\ ${ }^{1)}$ Alumni Magister Ilmu Akuntansi Pascasarjana Universitas Jambi Tahun 2020, \\ ${ }^{2 \& 3)}$ Dosen Fakultas Ekonomi dan Bisnis Universitas Jambi \\ Email: marizhadwi83@gmail.com ${ }^{1)}$ srijambi@gmail.com²)Ilham_wahyudi@unja.ac.id ${ }^{3)}$
}

\begin{abstract}
This research is aimed to provide empirical evidence of Capital Adequacy Ratio, Non Performing Loan, Profitability and Company Size by Liquidity Ratio. The population of this research are banking companies listed in Indonesia Stock Exchange (IDX) in 2013-2018. This research was using purposive sampling method; the samples were selected by specified characteristics. This research was using regression model with data panel. There are some results found on this research. It shows that all the ratios; Capital Adequacy Ratio, Non Performing Loan, Profitability and Banking Size, have simultanous effect on liquidity ratio. It also shows that only profitability has significant effect on liquidity ratio, meanwhile each of the other ratios; Adequacy Ratio, Non Performing Loan, and Banking Size does not have significant effect on liquidity ratio of banking corporations.
\end{abstract}

Keyword: Capital Adequacy Ratio, Non Performing Loan, Profitability, Company Size, Liquidity Ratio.

\begin{abstract}
ABSTRAK
Penelitian ini bertujuan untuk memberikan bukti secara empiris pengaruh kecukupan modal, risiko kredit, profitabilitas, dan ukuran bank secara simultan terhadap likuiditas. Populasi penelitian ini adalah perusahaan perbankan yang terdaftar di Bursa Efek Indonesia (BEI) periode tahun 2013 - 2018. Teknik penarikan sampel penelitian adalah dengan menggunakan metode purposive sampling yaitu sampel dipilih atas dasar kesesuaian karakteristik sampel dengan kriteria pemilihan sampel yang ditentukan. Analisis data dalam penelitian ini menggunakan model regresi data panel. Hasil penelitian ini menunjukkan bahwa keseluruhan rasio; kecukupan modal, risiko kredit, profitabilitas, dan ukuran bank, memiliki pengaruh secara simultan terhadap rasio likuiditas. Hasil penelitian ini juga menunjukan bahwa hanya rasio profitabilitas yang memiliki pengaruh signifikan terhadap rasio likuiditas, sedangkan tiga rasio lainnya yaitu rasio kecukupan modal, risiko kredit dan ukuran perusahaan yang tidak memiliki pengaruh pada rasio likuiditas perusahaan perbankan.
\end{abstract}

Kata Kunci: Kecukupan Modal, Risiko Kredit, Profitabilitas, Ukuran Bank, Likuiditas. 


\section{PENDAHULUAN}

\subsection{Latar Belakang Penelitian}

Bank dan industri perbankan secara keseluruhan sebagai lembaga intermediasi sektor keuangan, memiliki peran penting dalam perekonomian suatu negara. Secara mikro, bank berfungsi menyalurkan dana dari nasabah yang memiliki kelebihan dana kepada pelaku usaha dan perorangan yang membutuhkan dana dalam rangka memperlancar usaha dari pihak-pihak yang berkepentingan. Secara makro, industri perbankan berperan sebagai sumber pembiayaan bagi perkembangan perekonomian dan sebagai sarana dalam pelaksanaan kebijakan moneter (KNKG, 2012).

Likuiditas merupakan salah satu indicator kesehatan perbankan, merupakan penentu apakah bank tersebut mampu membayar kembali kewajibankewajiban kepada deposannya. Secara teoritis, bagi perbankan likuiditas merupakan "darah" bagi kehidupan. Apabila bank mengalami kekeringan likuiditas, maka bank ini tengah dihadapkan pada persoalan serius yang harus segera diselesaikan. Kalau tidak, maka besar kemungkinan bank akan dilikuidasi karena secara teknis bank dinilai tidak layak beroperasi (Dendawijaya, 2009). Rasio likuiditas yang umum digunakan dalam dunia perbankan diukur melalui Loan to Deposit Ratio (LDR). Berdasakan Peraturan Bank Indonesia Nomor 17/11/PBI/2015 tentang Giro Wajib Minimum Bank Umum dalam Rupiah dan Valuta Asing Bagi Bank Umum Konvensional disebutkan bahwa batas bawah LFR yaitu sebesar 78\%, sedangkan batas atas LFR yaitu sebesar $92 \%$.

\section{Tabel 1. Perkembangan Likuiditas Perusahaan Perbankan Yang Terdaftar di BEI Tahun 2013 - 2018}

\begin{tabular}{|l|c|c|c|c|c|c|}
\hline \multirow{2}{*}{ Interval Nilai LFR } & \multicolumn{6}{|c|}{ Jumlah Perusahaan pada Tahun } \\
\cline { 2 - 7 } & 2013 & 2014 & 2015 & 2016 & 2017 & 2018 \\
\hline $\begin{array}{l}\text { Sesuai dengan } \\
\text { Peraturan Bank } \\
\begin{array}{l}\text { Indonesia (78\%- } \\
92 \%)\end{array}\end{array}$ & 20 & 19 & 21 & 19 & 18 & 14 \\
\hline $\begin{array}{l}\text { Tidak Sesuai } \\
\text { dengan Peraturan } \\
\text { Bank Indonesia } \\
\text { (78\%-92\%) }\end{array}$ & 15 & 16 & 14 & 16 & 17 & 21 \\
\hline Jumlah & 35 & 35 & 35 & 35 & 35 & 35 \\
\hline
\end{tabular}

Data di atas menunjukkan bahwa likuiditas perusahaan perbankan yang terdaftar di BEI selama periode tahun 2013 - 2018 yang memenuhi ambang batas yang ditetapkan dalam Peraturan Bank Indonesia mengalami penurunan, dimana pada tahun 2013-2018, jumlah perusahaan yang tidak memenuhi ambang batas likuiditas terus meningkat. Pada tahun 2013 jumlah perusahaan yang tidak memenuhi ambang batas likuiditas sebanyak 15 perusahaan sedangkan pada tahun 2018 sebanyak 21 perusahaan.

Beberapa perusahaan perbankan mengalami penurunan nilai likuiditas sampai berada di bawah ambang batas yang ditetapkan artinya perusahaan perbankan dalam posisi kesulitan menjamin simpanan nasabahnya, sehingga kelangsungan operasional perusahaan perbankan terancam. Sementara itu, beberapa perusahaan perbankan lainnya yang terdaftar di BEI justru mengalami kenaikan rasio likuiditas sampai melebihi batas maksimum yang ditetapkan. Rasio likuiditas yang terlalu tinggi mengindikasikan tidak efisiennya pengelolaan kas, sehingga terjadi adanya kas menganggur dalam jumlah besar yang mengindikasikan perkembangan operasional perusahaan yang mengalami perlambatan (ASA Consulting, 2012).

Kasus-kasus Bank yang dilikuidasi karena tidak mampu membayar kewajiban jangka pendeknya seringkali terjadi di Indonesia. Fenomena kebangkrutan Bank di Indonesia telah bisa kita lihat sejak krisis 1998 dimana kebanyakan darinya diselamatkan pemerintah. Pada era reformasi ini beberapa kasus juga terjadi di luar krisis keuangan meskipun BI telah menerapkan regulasi yang sangat ketat. Berdasarkan data dari Lembaga PenjaminSimpanan (LPS), selama periodetahun 2010 - 2017, sebanyak 45 bank di Indonesia telah dilikuidasi dan 35 bank lainnya sedangdalam proses likuidasi (LPS, 2018).

Modal merupakan fondasi awal yang sangat penting untuk diperhatikan apabila suatu entitas ekonomi akan mendirikan usaha. Semakin besar nilai modal yang dimiliki maka entitas tersebut dapat memulai usahanya dengan baik, seperti melaksanakan kegiatan operasionalnya dan pengembangan skala usahanya, demikian pula dengan perbankan. Seluruh bank di Indonesia diwajibkan untuk menyediakan modal minimum atau kewajiban penyediaan modal minimum (KPMM). Tujuan ditetapkannya modal minimum bank adalah untuk menutupi kemungkinan timbulnya risko-risiko kerugian dari aktiva yang mengandung risiko. Bank wajib menyediakan modal minimum sesuai profil risiko. Penyediaan modal minimum tersebut sesuai dengan Aktiva Tertimbang Menurut Risiko (ATMR) perusahaan perbankan. Capital Adequacy Ratio merupakan rasio yang menunjukkan besarnya kecukupan modal yang dimiliki bank. Semakin tinggi kecukupan modal bank, semakin besar pula kemampuan bank dalam memenuhi kewajiban likuiditasnya.

Profitabilitas merupakan faktor lain yang mempengaruhi kegiatan usaha perbankan. Tujuan utama dari operasional perbankan adalah memperoleh tingkat profitabilitas yang tinggi. Menurut Harahap (2009), rasio profitabilitas menggambarkan kemampuan perusahaan mendapatkan laba melalui semua kemampuannya, dan sumber yang ada seperti kegiatan penjualan, kas, ekuitas, jumlah karyawan, jumlah cabang dan sebagainya. Rasio profitabilitas merupakan ukuran penting yang dapat digunakan untuk menilai sehat tidaknya perusahaan dengan menggunakan perbandingan antara laba setelah pajak yang mampu diperoleh terhadap pemanfaatan aset yang dimiliki. 
Di sisi lain, salah satu kegiatan operasional perbankan untuk meningkatkan profitabilitasnya adalah dengan menyalurkan dana kepada debitur. Dana tersebut disalurkan dalam bentuk pinjaman atau kredit. Setiap kredit yang disalurkan memiliki tingkat risiko kredit, yaitu berupa tidak lancarnya pembayaran kredit. Risiko kredit adalah risiko dari kemungkinan terjadinya kerugian bank sebagai akibat dari tidak dilunasinya kembali kredit yang diberikan bank kepada debitur. Menurut Dendawijaya (2009), kredit bermasalah dapat diukur dari kolektibilitasnya dengan criteria kurang lancar, diragukan dan macet. Kemacetan fasilitas kredit disebabkan oleh tiga factor yaitu factor ekstern, faktor intern dari pihak perbankan dan faktor intern dari pihak nasabah.

Non Performing Loan adalah perbandingan antara total kredit bermasalah dengan total kredit yang diberikan kepada debitur. Apabila suatu bank mempunyai NPL yang tinggi, maka akan memperbesar biaya, baik biaya pencadangan aktiva produktif maupun biaya lainnya. Semakin besar tingkat NPL ini menunjukkan bahwa bank tersebut tidak professional dalam pengelolaan kreditnya, sekaligus memberikan indikasi bahwa tingkat risiko atas pemberian kredit pada bank tersebut cukup tinggi searah dengan tingginya NPL yang dihadapi bank.

Besar kecilnya ukuran perusahaan perbankan juga memiliki peluang yang lebih besar dalam meningkatkan risiko yang harus ditanggung oleh pihak bank. Apabila aset yang dimiliki pihak bank mengalami peningkatan maka terdapat peluang dalam penempatan dana di sektor kredit. Hal itu terjadi apabila aset yang dimiliki bank tersebut tidak dikelola dan digunakan secara maksimal untuk kegiatan operasional bank, sehingga bank akan berpotensi mengeluarkan biaya pengelolaan aset yang lebih besar. Semakin besar aktiva atau assets yang dimiliki suatu bank maka semakin besar pula volume kredit yang dapat disalurkan oleh bank tersebut. Ukuran bank yang besar lebih diinginkan karena memungkinkan bank menyediakan menu jasa keuangan yang lebih luas. Dengan luasnya jasa keuangan yang ditawarkan, maka berpengaruh dalam menjaga likuiditas bank tersebut.

Penelitian mengenai pengaruh profitabilitas, kecukupan modal dan risiko kredit terhadap likuiditas perbankan telah dilakukan oleh Shamas, et.al. (2018) dengan judulThe Impact of Bank's Determinants on Liquidity Risk: Evidence from Islamic Banks in Bahrain. Hasil penelitian tersebut menunjukkan bahwa likuiditas berhubungan dengan profitabilitas perbankan, sedangkan risiko kredit (NPL) dan kecukupan modal (CAR) berpengaruh negatif dan signifikan terhadap risiko likuiditas perbankan. Sementara itu, ukuran bank dan krisis keuangan di Bahrain menunjukkan pengaruh negatif namun tidak signifikan terhadap likuiditas.

Penelitian ini merupakan pengembangan dari penelitian yang dilakukan oleh Shamas, et.al. (2018) untuk meneliti kembali pengaruh kecukupan modal, risiko kredit, profitabilitas dan ukuran bank terhadap likuiditas bank dengan menghilangkan faktor krisis keuangan dikarenakan di Indonesia sedang tidak terjadi krisis keuangan. Perbedaan penelitian ini dengan penelitian sebelumnya yaitu perbedaan subjek penelitian, dimana dalam penelitian Shamas, et.al., menggunakan Bank Islam, sedangkan dalam penelitian ini menggunakan bank konvensional

Berdasarkan latar belakang tersebut, maka peneliti tertarik untuk melakukan penelitian dengan judul "Pengaruh Kecukupan Modal, Risiko Kredit, Profitabilitas, dan Ukuran Bank terhadap Likuiditas (Studi pada Perusahaan Perbankan yang Terdaftar di BEI Tahun 2013 - 2018)"

\subsection{Rumusan Masalah}

Berdasarkan latar belakang yang telah dijelaskan di atas, maka rumusan masalah yang akan diteliti dalam penelitian ini adalah:

1. Apakah kecukupan modal, risiko kredit, profitabilitas, ukuran bank, suku bunga SBI, dan inflasi secara simultan berpengaruh terhadap likuiditas?

2. Apakah kecukupan modal berpengaruh terhadap likuiditas?

3. Apakah kredit bermasalah berpengaruh terhadap likuiditas?

4. Apakah profitabilitas berpengaruh terhadap likuiditas?

5. Apakah ukuran bank berpengaruh terhadap likuiditas?

\subsection{Tujuan Penelitian}

Tujuan penelitian ini adalah sebagai berikut:

1. Membuktikan secara empiris pengaruh kecukupan modal, risiko kredit, profitabilitas, dan ukuran bank secara simultan terhadap likuiditas.

2. Membuktikan secara empiris pengaruh kecukupan modal terhadap likuiditas.

3. Membuktikan secara empiris pengaruh kredit bermasalah terhadap likuiditas.

4. Membuktikan secara empiris pengaruh profitabilitas terhadap likuiditas.

5. Membuktikan secara empiris pengaruh ukuran bank terhadap likuiditas.

\section{TINJAUAN PUSTAKA}

\subsection{Likuiditas}

Menurut Joseph E. Burns, Likuiditas bank berkaitan dengan kemampuan suatu bank untuk menghimpun sejumla tertentu dana dengan biaya tertentu dan dalam jangka waktu tertentu. Pernyataan tersebut sependapat dengan Oliver G. Wood, Jr yang 
menyatakan bahwa Likuiditas adalah kemampuan bank untuk memenuhi semua penarikan dana oleh nasabah deposan, kewajiban yang telah jatuh tempo dan memenuhi permintaan kredit tanpa penundaan. Tak berbeda jauh, Wiliam M. Glavin menyatakan bahwa Likuiditas berarti memiliki sumber dana yang cukup tersedia untuk memenuhi semua kewajiban.Dalam penelitian ini mencakup 2 kategori yaitu kepemilikan institusional dan kepemilikan manajerial.

Likuiditas bank menurut Josep E. Burns terdiri dari tiga unsur yaitu" jumlah dana, biaya dana, dan waktu yang digunakan untuk memenuhi kebutuhan likuiditas bank". Josep menambahkan, semakin besar jumlah dana yang dapat diperoleh suatu bank dalam waktu tertentu, untuk memenuhi likuiditasnya, dan dengan biaya yang telah ditetapkan, semakin likuid bank tersebut. Semakin cepat bank memperoleh sebuah dana dengan biaya tertentu, semakin tingi pula likuiditas bank yang bersangkutan. Selanjutnya, semakin rendah biaya dana yang diperolehnya tersebut dalam suatu periode tertentu, semain likuid pula bank yang bersangkutan.

Kasmir (2010) mengartikan bahwa likuiditas merupakan rasio untuk mengukur kemampuan bank dalam memenuhi kewajiban jangka pendeknya pada saat ditagih. Dengan kata lain dapat membayar kembali pencairan dana deposannya pada saat diagih serta dapat mencukupi permintaan kredit yang telah diajukan. Dikatakan likuid jika pada saat ditagih bank mampu membayar. Kemudian bank juga harus dapat pula memenuhi semua permohonan kredit yang layak dibiayai. Dalam penelitian ini, rasio likuiditas yang digunakan adalah Loan to Deposit Ratio (LDR), hal ini dikarenakan LDR dapat mengukur kemampuan manajemen bank dalam mengembangkan penyaluran kredit yang dananya berasal dari pihak ketiga.

Menurut Sudirman (2013) rasio likuiditas yang umum digunakan dalam dunia perbankan diukur melalui Loan to Deposit Ratio (LDR). LDR merupakan pengukuran terhadap seluruh kredit yang diberikan dengan dana pihak ketiga sebagai upaya penilaian terhadap kinerja bank. LDR berfungsi sebagai faktor penentu besar kecilnya giro wajib minimum (GWM) serta indikator intermediasi bank.

Berdasakan Peraturan Bank Indonesia Nomor 17/11/PBI/2015 Tentang Perubahan Atas Peraturan Bank Indonesia Nomor 15/15/PBI/2013 Tentang Giro Wajib Minimum Bank Umum dalam Rupiah dan Valuta Asing Bagi Bank Umum Konvensional menyebutkan bahwa batas bawah LDR yaitu sebesarr $78 \%$, sedangkan batas atas LDR yaitu sebesar $92 \%$.

\subsection{Kecukupan Modal}

Modal merupakan faktor yang amat penting bagi perkembangan dan kemajuan bank sekaligus menjaga kepercayaan masyarakat. Setiap penciptaan aktiva, disamping berpotensi menghasilkan keuntungan juga berpotensi menimbulkan terjadinya risiko. Oleh karena itu modal juga harus dapat digunakan untuk menjaga kemungkinan terjadinya risiko kerugian atas aktiva dan investasi pada aktiva, terutama yang berasal dari danadana pihak ketiga atau masyarakat. Peningkatan peran aktiva sebagai penghasil keuntungan harus secara simultan dibarengi dengan pertimbangan risiko yang mungkin timbul guna melindungi kepentingan para pemilik dana. Jika bank tersebut sudah beroperasi maka modal merupakan salah satu faktor yang sangat penting bagi pengembangan usaha dan menampung risiko kerugian.

Perhitungan penyediaan modal minimum atau kecukupan modal bank (capital adequacy) didasarkan pada rasio atau perbandingan antara modal yang dimiliki bank dan jumlah aktiva tertimbang menurut risiko (ATMR). ATMR merupakan penjumlahan ATMR aktiva neraca (aktiva yang tercantum dalam neraca) dan ATMR aktiva administrative (aktiva yang bersifat administratif) (Surat Edaran Bank Indonesia Nomor 13/24/DPNP).

Rasio kecukupan permodalan perbankan di Indonesia berdasarkan Surat Edaran Bank Indonesia Nomor 13/24/DPNP tanggal 25 Oktober 2011 tentang Penilaian Tingkat Kesehatan Bank Umum diukur menggunakan Capital Adequacy Ratio (CAR). Besarnya CAR diukur dari rasio antara modal sendiri terhadap Aktiva Tertimbang Menurut Risiko (ATMR). Sesuai dengan Peraturan Otoritas Jasa Keuangan Nomor 11/POJK.03/2016 tentang Kewajiban Penyediaan Modal Minimum Bank Umum menyebutkan bahwa Bank wajib menyediakan modal minimum sesuai profil risiko. Penyediaan modal minimum dihitung dengan menggunakan rasio Kewajiban Penyediaan Modal Minimum (KPMM). Penyediaan modal minimum ditetapkan paling rendah sebagai berikut:

a. 8\% (delapan persen) dari Aset Tertimbang Menurut Risiko (ATMR) untuk Bank dengan profil risiko peringkat 1 (satu);

b. $9 \%$ (sembilan persen) sampai dengan kurang dari $10 \%$ (sepuluh persen) dari ATMR untuk Bank dengan profil risiko peringkat 2 (dua);

c. $10 \%$ (sepuluh persen) sampai dengan kurang dari $11 \%$ (sebelas persen) dari ATMR untuk Bank dengan profil risiko peringkat 3 (tiga); atau

d. $11 \%$ (sebelas persen) sampai dengan 14\% (empat belas persen) dari ATMR untuk Bank dengan profil risiko peringkat 4 (empat) atau peringkat 5 (lima).

\subsection{Risiko Kredit}

Menurut Hardanto (2006), mengemukakan bahwa risiko kredit adalah risiko kerugian yang berhubungan dengan peluang gagal memenuhi kewajiban pada saat jatuh tempo. Dengan kata lain, risiko kredit adalah risiko karena peminjam tidak membayar utangnya. Risiko kredit timbul dari beberapa kemungkinan sebagai berikut:

a. Debitur tidak dapat melunasi utangnya.

b. Obligasi yang dibeli Bank, tidak membayar kupon dan atau pokok utang. 
c. Terjadinya non-performance (gagal bayar) dari semua kewajiaban antara bank dengan pihak lain.

Berdasarkan Peraturan Bank Indonesia Nomor 14/15/PBI/2012 tentang Penilaian Kualitas Aset Bank Umum, disebutkan bahwa dalam melaksanakan kegiatan usahanya, bank perlu mengelola risiko kredit antara lain dengan menjaga kualitas aset dan tetap melakukan penghitungan penyisihan penghapusan asset. Kasmir (2010) mengatakan bahwa asset (Kualitas Asset) dinilai berdasarkan kepada kualitas aktiva yang dimiliki bank. Aset (Aktiva) terdiri atas aktiva produktif dan aktiva non produktif. Menurut Peraturan Bank Indonesia Nomor 14/15/PBI/2012 tentang Penilaian Kualitas Aset Bank Umum, aktiva produktif didefinisikan sebagai penyediaan dana Bank untuk memperoleh penghasilan dalam bentuk kredit, surat berharga, penempatan dana antar bank, tagihan akseptasi, tagihan atas surat berharga yang dibeli dengan janji dijual kembali (reverse repurchase agreement), tagihan derivatif, penyertaan, transaksi rekening administratif serta bentuk penyediaan dana lainnya yang dapat dipersamakan dengan itu.

Alat ukur yang digunakan untuk mengukur risiko kredit dalam penelitian ini adalah Non Performing Loan (NPL). Non Performing Loan adalah perbandingan antara total kredit bermasalah dengan total kredit yang di berikan kepada debitur. Apabila suatu bank mempunyai NPL yang tinggi, maka akan memperbesar biaya, baik biaya pencadangan aktiva produktif maupun biaya lainnya, dengan kata lain semakin tinggi NPL suatu bank, maka hal tersebut akan mengganggu kinerja bank tersebut. Dendawijaya (2009) mengemukakan dampak dari keberadaan NPL yang tidak wajar salah satunya adalah hilangnya kesempatan memperoleh income (pendapatan) dari kredit yang diberikan, sehingga mengurangi perolehan laba dan berpengaruh buruk bagi profitabilitas bank.

\subsection{Profitabilitas}

Profitabilitas adalah kemampuan perusahaan dalam menghasilkan laba. Menurut Sartono (2010), profitabilitas adalah kemampuan perusahaan memperoleh laba dalam hubungannnya dengan penjualan, total aktiva maupun modal sendiri. Para investor tetap tertarik terhadap profitabilitas perusahaan karena profitabilitas mungkin merupakan satu-satunya indikator yang paling baik mengenai kesehatan keuangan perusahaan.

Return on Asset (ROA) menurut Surat Edaran Bank Indonesia No.13/24/DPNP digunakan sebagai proksi dalam mengukur profitabilitas suatu bank. Return on Asset digunakan karena merupakan rasio profitabilitas yang penting bagi bank dan digunakan untuk mengukur efektivitas bank dalam menghasilkan laba dengan memanfaatkan total aktiva-aktiva yang dimilikinya. Rasio ini digunakan untuk mengukur kemampuan manajemen bank dalam memperoleh keuntungan (laba) secara keseluruhan. Semakin besar ROA suatu bank, semakin besar pula tingkat keuntungan yang dicapai bank tersebut dan semakin baik pula posisi bank tersebut dari segi penggunaan aset.

\subsection{Ukuran Perusahaan}

Menurut Brigham dan Houston (2010) ukuran perusahaan merupakan ukuran besar kecilnya sebuah perusahaan yang ditunjukan atau dinilai oleh total asset, total penjualan, jumlah laba, beban pajak dan lain-lain. Sedangkan menurut Hartono (2008) ukuran perusahaan (firm size) adalah besar kecilnya perusahaan dapat diukur dengan total aktiva/ besar harta perusahaan dengan menggunakan perhitungan nilai logaritma total aktiva.

Menurut Ghozali (2006) mengungkapkan bahwa penilaian ukuran perusahaan dapat menggunakan tolak ukur total asset. Dalam penelitian ini, peneliti menggunakan proksi total asset, hal ini dimaksudkan untuk mengurangi fluktuasi data yang berlebih. Jika nilai total asset langsung dipakai begitu saja maka nilai variabel akan sangat besar, miliar bahkan triliun. Karena total asset perusahaan bernilai besar maka hal ini dapat disederhanakan dengan mentransformasikannya kedalam logaritma natural, tanpa mengubah proporsi dari nilai asal yang sebenarnya.

\section{METODOLOGI PENELITIAN}

\subsection{Objek Penelitian}

Penelitian ini merupakan penelitian kuantitatif bersifat hubungan causal explanatory yang bertujuan mengetahui pola hubungan kausal antara variabel independen dan variabel dependen. Penggunaan metode causal explanatory sesuai dengan tujuan penelitian yaitu melakukan pengujian hipotesa yang menguji hubungan dan pengaruh diantara variabel yang diteliti. Pemilihan jenis penelitian ini sesuai dengan tujuan penelitian, yaitu untuk mengetahui apakah kecukupan modal, risiko kredit, profitabilitas dan ukuran perusahaan berpengaruh terhadap likuiditas perusahaan.

Objek yang diteliti dalam penelitian ini adalah variabel yang terkait dalam penelitian yaitu likuiditas yang merupakan variabel dependen, sedangkan kecukupan modal, risiko kredit, profitabilitas dan ukuran perusahaan merupakan variabel independen. Subjek Penelitian ini adalah perusahaan perbankan yang terdaftar di BEI periode 2013 - 2018.

\subsection{Populasi dan Sampel}

Populasi penelitian ini adalah perusahaan perbankan yang listing dari tahun 2013 - 2018 di Bursa Efek Indonesia. Teknik penarikan sampel penelitian adalah dengan menggunakan metode purposive sampling yaitu sampel dipilih atas dasar kesesuaian karakteristik sampel dengan kriteria pemilihan sampel yang ditentukan.

Proses purposive sampling dalam penelitian dapat dilihat pada tabel berikut ini: 
Tabel 2. Proses Purposive Sampling Penelitian

\begin{tabular}{|r|l|c|}
\hline \multicolumn{1}{|c|}{ No } & \multicolumn{1}{|c|}{ Purposive Sampling } & Jumlah \\
\hline 1 & Perusahaan Perbankan di BEI & $(43)$ \\
\hline 2 & Dikurangi Perusahaan yang tidak listing selama periode penelitian 2013-2018. & $(8)$ \\
\hline \multicolumn{2}{|c|}{ Jumlah } & $(35)$ \\
\hline
\end{tabular}

\subsection{Analisis Data}

Analisis data dalam penelitian ini dilakukan dengan metode regresi data panel dengan menggunakan software Eviews.

\subsubsection{Uji Asumsi Klasik}

Penggunaan alat statistik regresi berganda mensyaratkan dilakukannya pengujian asumsi klasik. Hal ini diperlukan untuk menghindari masalah regresi, yaitu permasalahan pada uji asumsi klasik yang biasanya terdapat pada penelitian yang menggunakan lebih dari 2 variabel penjelas dan data runtut waktu. Jika terjadi penyimpangan asumsi klasik maka koefisien tidak dapat digunakan sebagai penaksir dengan ketepatan tinggi.

a. Uji Normalitas

Uji Normalitas bertujuan untuk menguji apakah variabel bebas, variabel tidak bebas atau keduanya mempunyai distribusi normal atau tidak. Salah satu cara untuk melihat normalitas residual adalah dengan menggunakan metode jarque-bera (JB). Apabila nilai JB lebih kecil dari 2 maka data berdistribusi normal atau jika probabilitas lebih besar dari $5 \%$ maka data berdistribusi normal. Uji Validitas

Pengujian validitas menggunakan Partial Least Square (PLS) dapat dilihat dari pengujian validitas convergent dan discriminant. Validitas convergent dihitung dengan melihat skor Average Variance Extracted (AVE). Nilai validitas convergent dikatakan sangat baik apabila skor AVE di atas 0,5 (Hussein, 2015).

\section{b. Uji Multikolinieritas}

Uji multikolinearitas bertujuan untuk mengetahui apakah terdapat hubungan kolinier antar variabel independen. Menurut Nachrowi dan Usman (2006), hampir seluruh data variabel dalam penelitian keuangan memiliki peluang multikolinier. Hal ini disebabkan variabel yang dipakai biasanya merupakan turunan dari variabel lain. Akibatnya, penggunaan dua variabel yang memiliki hubungan turunan dalam satu modelakan menimbulkan masalah multikolinieritas. c. Uji Auto Korelasi

Autokorelasi digunakan untuk menguji apakah dalam model suatu regresi linear ada korelasi kesalahan pengganggu pada periode " $\mathrm{t}$ " dengan kesalahan pengganggu pada periode "t1"(sebelumnya) dari serangkaian pengamatan yang tersususn dalam rangkaian waktu. Jika terjadi korelasi, maka dinamakan ada masalah autokorelasi. Untuk mendeteksi ada tidaknya autokorelasi digunakan Durbin Watson Test. Apabila nilai DW terletak dibatas atas, maka tidak ada autokorelasi.

d. Uji Heteroskedastisitas

Heteroskedastisitas merupakan suatu keadaan dimana varian dari kesalahan pengganggu tidak konstan untuk semua nilai variabel bebas. Dengan adanya heteroskedastisitas, perkiraan parameter berdasarkan OLS, masih "unbiased and consistent" akan tetapi tidak efisien, maksudnya mempunyai varian yang lebih besar daripada "minimum variance". Sehingga lebih lanjut perkiraan varian parameter akan biased dan menyebabkan pengujian hipotesa tentang parameter tidak tepat, interval keyakinan menjadi bias (biased confidence intervals).

\subsubsection{Pengujian Hipotesis}

Untuk pengujian hipotesis atas pengaruh kecukupan modal, risiko kredit, profitabilitas dan ukuran perusahaan terhadap likuiditas perusahaan dilakukan dengan melakukan perbandingan antara hasil regresi data panel dengan $t_{\text {tabel }}$. Hipotesis dapat dikatakan sangat signifikan apabila $t_{\text {hitung }}>t_{\text {tabel }}$ dan nilai $p$-value lebih kecil dari taraf signifikansi $\alpha=0,05$.

\section{HASIL DAN PEMBAHASAN}

\subsection{Uji Asumsi Klasik}

Analisis ini dilakukan untuk menghindari masalah regresi, yaitu permasalahan pada uji asumsi klasik yang biasanya terdapat pada penelitian yang menggunakan lebih dari 2 variabel penjelas dan data runtut waktu.

Tabel 3. Hasil Uji Multikolinearitas

\begin{tabular}{|l|c|c|r|r|}
\hline \hline & CAR & NPL & \multicolumn{1}{c|}{ ROA } & \multicolumn{1}{c|}{ UKPRSH } \\
\hline \hline CAR & 1.000 .000 & -0.113512 & 0.044431 & -0.144026 \\
\hline NPL & -0.113512 & 1.000 .000 & -0.024676 & -0.199913 \\
\hline ROA & 0.044431 & -0.024676 & 1.000 .000 & 0.077684 \\
\hline
\end{tabular}


Pengaruh Kecukupan Modal, Risikokredit, Profitabilitas, dan Ukuran Bank Terhadap Likuiditas (Studi Pada Perusahaan Perbankan yang Terdaftar di Bei Tahun 2013 - 2018) (Marizha Dwi R, Sri Rahayu dan Ilham Wahyudi)

\begin{tabular}{|l|r|r|r|r|} 
UKPRSH & -0.144026 & -0.199913 & 0.077684 & 1.000 .000 \\
\hline \hline Sumber: output eviews
\end{tabular}

Sumber: output eviews

Berdasarkan pengujian terhadap nilai koefisien korelasi di atas, masing-masing variabel mempunya nilai koefisien $<0.9$, maka dapat disimpulkan bahwa model tidak mengalami masalah multikolinearitas.

Tabel 4. Hasil Uji Auto Korelasi

\begin{tabular}{lllr}
\hline \hline R-squared & 0.803302 & Mean dependent var & 0.850872 \\
Adjusted R-squared & 0.759591 & S.D. dependent var & 0.145863 \\
S.E. of regression & 0.071519 & Akaike info criterion & -2.271723 \\
Sum squared resid & 0.874659 & Schwarz criterion & -1.650118 \\
Log likelihood & 277.5309 & Hannan-Quinn criter. & -2.020431 \\
F-statistic & 18.37772 & Durbin-Watson stat & 1.907741 \\
Prob(F-statistic) & 0.000000 & & \\
\hline \hline
\end{tabular}

Sumber: output eviews

Berdasarkan Tabel 4 tersebut, nilai dari Durbin Watson adalah 1,907741. Jumlah observasi (N) adalah 210 dan jumlah variabel bebas dan terikat adalah 5, maka berdasarkan tabel Durbin Watson nilai dl dan du nya adalah 1,73537 dan 1,81295, nilai (4-dl) dan (4-du) adalah 2,26463 dan 2,18705.

Berdasarkan dari nilai tersebut, maka dapat disimpulkan bahwa nilai Durbin Watson terletak antara batas atas atau upper bound (du) dan (4-du) yaitu $1,81295<1,907741<2,18705 \quad(\mathrm{du}<\mathrm{dw}<(4-\mathrm{du}))$, maka koefisien autokorelasi sama dengan nol, berarti tidak ada autokorelasi.

Menurut Ajija, Shochrul Rohmatul dkk (2011) uji normalitas hanya digunakan jika jumlah observasi adalah kurang dari 30, untuk mengetahui apakah error term mendekati distribusi normal. Jika jumlah observasi lebih dari 30, tidak perlu dilakukan uji normalitas. Sebab, distribusi sampling error term telah mendekati normal. Jumlah observasi pada penelitian ini adalah 210 observasi sehingga tidak dibutuhkan untuk dilakukan uji normalitas data. selanjutnya. Sementara itu nilai AVE pada variabel laten asimetri informasi, dan manajemen laba riil sebesar 1,000 yang berarti bahwa semua indikator pada masing-masing variabel laten mampu mampu mengukur dengan baik variabel latennya.

\subsection{Pemilihan Model Regresi Data Panel}

Dalam data panel kita dapat melakukan tiga pendekatan untuk mengestimasi, oleh karena itu perlu melakukan pengujian untuk menentukan mana diantara ketiga pendekatan tersebut yang paling sesuai dengan data yang digunakan. Pendekatan analisis data panel antara lain dengan metode common effect, fixed effect dan random effect.

\subsubsection{Uji Chow}

Pengujian tersebut dibutuhkan untuk memilih model yang paling tepat diantara model common effect dan fixed effect.

Tabel 5. Hasil Uji Chow

\begin{tabular}{|c|c|c|c|}
\hline Effects Test & Statistic & d.f. & Prob. \\
\hline Cross-section F & 18.655874 & $(34,171)$ & 0.0000 \\
\hline Cross-section Chi-square & 325.405701 & 34 & 0.0000 \\
\hline
\end{tabular}

Hasil dari uji chow pada tabel 5 menunjukkan bahwa nilai probabilitas cross section adalah 0,0000 atau $<0,05$, maka H0 ditolak. Oleh karena itu model yang dipilih adalah fixed effect. Selanjutnya kita akan melakukan regresi dengan model random effect, untuk menentukan model mana yang tepat.

\subsubsection{Uji Hausmant Test}

Pada tabel sebelumnya yang menggunakan fixed effect dan tabel di atas yang menggunakan model random effect, semuanya menunjukkan hasil variabel independen berpengaruh signifikan terhadap variabel dependen yaitu likuiditas perusahaan. Namun belum dapat menentukan model mana yang akan kita gunakan. Oleh karena itu diperlukan uji hausman untuk mengetahuinya. 
Tabel 6. Uji Hausmant Test

\begin{tabular}{lrrr}
\hline \hline Test Summary & Chi-Sq. Statistic & Chi-Sq. d.f. & Prob. \\
\hline \hline Cross-section random & 2.064649 & 4 & 0.7239 \\
\hline \hline
\end{tabular}

Sumber: output eviews

Berdasarkan hasil uji hausman di atas, dapat dilihat dari nilai probabilitas Cross-section random yakni sebesar 0.7239 nilai tersebut lebih besar dari 0.05, ini berarti H0 diterima dan ditolak H1 sehinga model yang dipilih yakni Random Efek.

\subsection{Pengujian Hipotesis}

Untuk melihat besarnya pengaruh variabel kecukupan modal, risiko kredit, profitabilitas dan ukuran perusahaan secara parsial terhadap likuiditas perusahaan digunakan Uji F. Pengujian simultan atau uji f ini digunakan untuk menguji pengaruh setiap variabel independen terhadap variabel dependennya.

Apabila nilai probabilitas f lebih kecil dari 0,05 maka hasilnya signifikan berarti terdapat pengaruh dari variabel independen secara individual terhadap variabel dependen.

Tabel 7. Hasil Pengujian Hipotesis

\begin{tabular}{crrrr}
\hline \hline Variable & Coefficient & Std. Error & t-Statistic & Prob. \\
\hline \hline C & 0.958201 & 0.245179 & 3.908170 & 0.0001 \\
CAR & 0.099958 & 0.157929 & 0.632930 & 0.5276 \\
NPL & 0.899827 & 0.583737 & 1.541494 & 0.1250 \\
ROA & 1.171199 & 0.371998 & 3.148406 & 0.0019 \\
UKRNPRSHN & -0.005108 & 0.007902 & -0.646512 & 0.5188 \\
\hline \hline
\end{tabular}

Effects Specification

Cross-section fixed (dummy variables)

\begin{tabular}{lllr}
\hline \hline R-squared & 0.803302 & Mean dependent var & 0.850872 \\
Adjusted R-squared & 0.759591 & S.D. dependent var & 0.145863 \\
S.E. of regression & 0.071519 & Akaike info criterion & -2.271723 \\
Sum squared resid & 0.874659 & Schwarz criterion & -1.650118 \\
Log likelihood & 277.5309 & Hannan-Quinn criter. & -2.020431 \\
F-statistic & 18.37772 & Durbin-Watson stat & 1.907741 \\
Prob(F-statistic) & 0.000000 & & \\
\hline \hline
\end{tabular}

Sumber: output eviews

\subsubsection{Pengaruh Kecukupan Modal terhadap Likuiditas} Perusahaan

Hasil pengujian analisis regresi data panel menunjukkan hasil t-hitung untuk variabel independen kecukupan modal adalah sebesar 0.632930, sementara nilai t-tabel dengan $\alpha=5 \%$ dan $\mathrm{df}=(\mathrm{n}-\mathrm{k})$, df $=205$ dimana nilai t-tabel adalah sebesar 2,600024 yang berarti bahwa nilai t-hitung lebih kecil dari nilai t-tabel $(0.632931<2,600024)$, maka H0 diterima. Hal ini berarti bahwa kecukupan modal tidak memiliki pengaruh terhadap likuiditas perusahaan.

\subsubsection{Pengaruh Risiko Kredit terhadap Likuiditas Perusahaan}

Dapat dilihat hasil pengujian dari tabel di atas dengan analisis regresi data panel yang menunjukkan bahwa thitung untuk variabel independen Risiko Kredit adalah sebesar 1.541494, sementara nilai t-tabel adalah sebesar 2,600024 yang berarti bahwa nilai t-hitung lebih kecil dari nilai t-tabel $(1.541495<2,600024)$. Hal ini menyatakan bahwa Risiko Kredit tidak memiliki pengaruh yang signifikan terhadap likuiditas perusahaan.

\subsubsection{Pengaruh Profitabilitas terhadap Likuiditas} Perusahaan

Dapat dilihat hasil pengujian dari tabel di atas menunjukkan hasil dari uji t dengan analisis regresi data panel yang menunjukkan hasil t-hitung untuk variabel independen Profitabilitas adalah sebesar 3.148406 sementara nilai t-tabel dengan $\alpha=5 \%$ adalah sebesar 2,600024 yang berarti bahwa nilai t-hitung lebih besar dari nilai t-tabel sebesar (3.148406>2,600024). Hal ini berarti menunjukkan bahwa Profitabilitas memiliki pengaruh yang signifikan terhadap Likuiditas Perusahaan.

\subsubsection{Ukuran Perusahaan terhadap Likuiditas Perusahaan}

Dilihat dari tabel di atas menunjukkan hasil dari uji $\mathrm{t}$ dengan analisis regresi data panel yang menunjukkan 
hasil t-hitung untuk variabel independen ukuran perusahaan adalah sebesar -0.646517 sementara nilai ttabel dengan $\alpha=5 \%$ adalah sebesar 2,600024 yang berarti bahwa nilai t-hitung lebih kecil dari t-tabel sebesar $\quad(-0.646517<2,600024)$. Hal ini berarti menunjukkan bahwa Ukuran Perusahaan tidak memiliki pengaruh terhadap Likuiditas Perusahaan.

\subsubsection{Pengaruh Variabel Kecukupan Modal, Risiko} Kredit, Profitabilitas dan Ukuran Perusahaan terhadap Likuiditas secara Simultan (Uji F)

Uji $F$ digunakan untuk mengetahui apakah variabel independen secara bersama-sama berpengaruh terhadap variabel dependen atau untuk mengetahui apakah model regresi dapat digunakan untuk memprediksi variabel dependen atau tidak.

Apabila nilai $\mathrm{F}$ hitung $>\mathrm{F}$ tabel maka $\mathrm{H} 0$ ditolak dan dapat disimpulkan bahwa variabel independen secara simultan mempengaruhi variabel dependennya. Apabila nilai $\mathrm{F}$ hitung < $\mathrm{F}$ tabel, maka $\mathrm{H} 0$ diterima dan dapat disimpulkan bahwa tidak ada variabel independen yang mempengaruhi variabel dependennya.

Berdasarkan hasil output Eviews di atas, nilai $\mathrm{F}$ hitung yaitu sebesar 18.37772 sementara $\mathrm{F}$ tabel dengan tingkat $\alpha=5 \%$ adalah sebesar 2,42. Dengan demikian $F$ hitung $>\mathrm{F}$ tabel $(18.37772>2,42)$, kemudian juga terlihat dari nilai probabilitas yaitu sebesar 0,0002 yang lebih kecil dari tingkat signifikansi sebesar 0,05 sehingga $\mathrm{H} 0$ diterima. Hal ini menunjukkan bahwa variabel Kecukupan Modal, Risiko Kredit, Profitabilitas dan Ukuran Perusahaan secara bersama-sama (simultan) mempunyai pengaruh yang signifikan terhadap likuiditas perusahaan, sehingga model regresi dapat digunakan untuk memprediksi variabel dependen.

\subsubsection{Koefisien Determinasi (Adjusted R-Square)}

Koefisien determinasi (Adjusted R-Square) pada intinya adalah untuk mengukur seberapa jauh kemampuan model dalam menerangkan variasi variabel dependennya. Nilai adjusted R-square yang mendekati satu berarti kemampuan variabel-variabel independen memberikan hampir semua informasi yang dibutuhkan untuk memprediksi variasi dependen.

Berdasarkan tabel di atas, besar angka Adjusted R-Square (R2) adalah 0.759591. Hal ini menunjukkan bahwa persentase sumbangan pengaruh variabel independen terhadap variabel dependen adalah sebesar 75,95\%. Atau dapat diartikan bahwa variabel independen yang digunakan dalam model mampu menjelaskan sebesar $75,95 \%$ terhadap variabel depedennya. Sisanya $24,05 \%$ lainnya dipengaruhi faktor lain di luar model regresi tersebut.

\section{SIMPULAN DAN SARAN}

\subsection{Simpulan}

Berdasarkan hasil penelitian dapat disimpulkan hal-hal sebagai berikut:
1. Kecukupan Modal dalam penelitian ini diukur dengan menggunakan Capital Adequacy Ratio (CAR) dan Likuiditas dalam penelitian ini diukur dengan menggunakan Loan to Deposit Ratio (LDR), Capital Adequacy Ratio (CAR) tidak berpengaruh terhadap Loan to Deposit Ratio (LDR).

2. Risiko Kredit dalam penelitian ini diukur dengan menggunakan Non Performing Loan (NPL) dan Likuiditas dalam penelitian ini diukur dengan menggunakan Loan to Deposit Ratio (LDR), Non Performing Loan (NPL) tidak berpengaruh terhadap Loan to Deposit Ratio (LDR).

3. Profitabilitas dalam penelitian ini diukur dengan menggunakan Return On Assets (ROA) dan Likuiditas dalam penelitian ini diukur dengan menggunakan Loan to Deposit Ratio (LDR), Return On Assets (ROA) berpengaruh terhadap Loan to Deposit Ratio (LDR).

4. Ukuran Perusahaan dalam penelitian ini diukur dengan menggunakan Ln dari Total Aset dan Likuiditas dalam penelitian ini diukur dengan menggunakan Loan to Deposit Ratio (LDR), Ukuran Perusahaan tidak berpengaruh terhadap Loan to Deposit Ratio (LDR).

5. Capital Adequacy Ratio (CAR), Non Performing Loan (NPL), Return On Assets (ROA) dan Ukuran Perusahaan berpengaruh secara simultan terhadap Loan to Deposit Ratio (LDR).

\subsection{Keterbatasan Penelitian}

Penelitian ini memiliki keterbatasan antara lain sebagai berikut:

1. Penelitian ini hanya menggunakan perusahaan perbankan yang terdapat pada Bursa Efek Indonesia.

2. Berdasarkan hasil penelitian ini, nilai adjusted Rsquared adalah $75 \%$ sehingga masih ada $25 \%$ factor-faktor yang mempengaruhi likuiditas berdasarkan variabel-variabel lainnya.

\subsection{Saran}

Berdasarkan kesimpulan hasil penelitian ini sebagaimana diuraikan di atas, maka peneliti menyumbangkan saran sebagai berikut:

1. Bagi peneliti selanjutnya supaya melakukan penelitian dengan subjek penelitian yang lebih beragam misalnya dengan menggunakan seluruh perusahaan Lembaga keuangan yang terdaftar di BEI.

2. Bagi peneliti selanjutnya supaya menggunakan faktor-faktor lainnya sebagai variabel yang mempengaruhi likuiditas perusahaan.

\section{DAFTAR REFERENSI}

Ahmad, Farooq dan Nasir Rasool. 2017. Determinants of Bank Liquidity: Empirical Evidence from Listed Commercial Banks with SBP. Journal of 
Economics and Sustainable Development www.iiste.org, ISSN 2222-1700 (Paper) ISSN 2222-2855 (Online), Vol.8, No.1, 2017.

Alzoubi, Tariq. 2017. Determinants of liquidity risk in Islamic banks. Banks and Bank Systems, Volume 12, Issue 3, 2017.

American Institute of Certified Public Accountants (AICPA), 2007. Consideration of Fraud in a Financial Statement Audit. AU Section 316. PCAOB Standards and Related Rules as of December 2006. New York, NY: AICPA.

Amir, Amri dan Junaidi. 2009. Metodologi Penelitian Ekonomi dan Penerapannya. Bogor: IPB Press.

Arens, Alvin A. James L. Loebbecke, 2008. Auditing Pendekatan Terpadu, Terjemahan oleh Amir Abadi Yusuf, Buku Dua, Edisi Indonesia, Salemba Empat, Jakarta.

Bank Indonesia. 2011. Surat Edaran Bank Indonesia nomor 13/24/DPNP tanggal 25 Oktober 2011 tentang Penilaian Tingkat Kesehatan Bank Umum. Diakses dari www.bi.go.id Tanggal 1 Maret 2018.

2012. Peraturan Bank Indonesia Nomor 14/15/PBI/2012 tentang Penilaian Kualitas Aset Bank Umum. Diakses dari www.bi.go.id Tanggal 1 Maret 2018.

2013. Peraturan Bank Indonesia Nomor 15/12/PBI/2013 tentang Kewajiban Penyediaan Modal Minimum Bank Umum. Diakses dari www.bi.go.id Tanggal 1 Maret 2018.

2015. Peraturan Bank Indonesia Nomor 17/11/PBI/2015 Tentang Perubahan Atas Peraturan Bank Indonesia Nomor 15/15/PBI/2013 Tentang Giro Wajib Minimum Bank Umum dalam Rupiah dan Valuta Asing Bagi Bank Umum Konvensional. Diakses dari www.bi.go.id Tanggal 27 April 2018.

Belaid, Faiçal, Meryem Bellouma, dan Abdelwahed Omri. 2016. Determinants of Liquidity Risk: Evidence from Tunisian Banks. International Journal of Emerging Research in Management \&Technology ISSN: 2278-9359 (Volume-5, Issue-6), Research Article June 2016.

Boediono 2005. Ekonomi Moneter. Edisi 3. Yogyakarta: BPFE.

Brigham, Eugene F. Dan J. F. Houston. 2010. Dasardasar Manajemen Keuangan Buku 1. (Edisi 11). Jakarta: Salemba Empat.

Dendawijaya, Lukman. 2009. Manajemen Perbankan. Bogor : Ghalia Indonesia.

Fola, Belete. 2015. Factors Affecting Liquidity of Selected Commercial Banks in Ethiopia. Thesis. Master of Science in Accounting and Finance. Addis Ababa University Ethiopia.
Ghozali, Imam, 2009. Aplikasi Analisis Multivariate Dengan Program SPSS, Edisi Keempat: Penerbit Universitas Diponegoro.

Gujarati, Damodar. 2006. Dasar-Dasar Ekonometrika, Terjemahan, Erlangga: Jakarta

Hadad, Muliaman D., Wimboh Santoso, dan Bambang Arianto. 2003. Indikator Awal Krisis Perbankan. Biro Stabilitas Sistem Keuangan, Direktorat Penelitian dan Pengaturan Perbankan. Diakses dari www.bi.go.id Tanggal 1 Maret 2017.

Hanafi, M. Madduh dan Abdul Halim, 2009, Analisa Laporan Keuangan. Edisi Keempat. Yogyakarta: Penerbit UPP AMP, YKPN.

Harahap, Sofyan Syafri. 2009. Analisis Kritis atas Laporan Keuangan. Edisi Pertama. Jakarta : Grafindo

Hartono, Jogiyanto. 2008. Teori Portofolio dan Analisis Investasi. Yogyakarta: BPFE.

Ikatan Akuntan Indonesia. 2009. Standar Akuntansi Keuangan. Jakarta: Salemba Empat.

Indriantoro, Nur dan Bambang Supomo. 2011, Metodologi Penelitian Bisnis Untuk Akuntansi dan Manajemen, Edisi Pertama. Yogyakarta: BPFE

Jumingan, 2006. Analisis Laporan Keuangan, Cetakan Pertama, Jakarta: PT Bumi Aksara..

Kasmir. 2011. Analisis Laporan Keuangan. Ed. 1-3. Jakarta: Rajawali Pers

Kuncoro, Mudrajad dan Suharjono. 2011. Manajemen Perbankan Teori dan Aplikasi. Edisi Pertama. Yogyakarta: BPFE Yogyakarta.

Kuncoro, Mudrajad. 2009. Metode Riset Untuk Bisnis \& Ekonomi. Jakarta: Penerbit. Erlangga.

Lartey, Victor Curtis, Samuel Antwi, dan Eric Kofi Boadi. 2013. The Relationship between Liquidity and Profitability of Listed Banks in Ghana. International Journal of Business and Social Science Vol. 4 No. 3; March 2013, www.ijbssnet.com.

Lembaga Penjamin Simpanan. 2017. Bank Yang Dilikuidasi. Diakses dari http://www.lps.go.id/web/guest/bank-yangdilikuidasi Tanggal 26 februari 2017

Madhi, Cand. Doris. 2017. The Macroeconomic Factors Impact on Liquidity Risk: The Albanian Banking System Case. European Journal of Economics and Business Studies Jan-Apr 2017 Vol. 7 Nr. 1 , ISSN 2411-9571 (Print) ISSN 2411-4073 (online).

Manurung, Mandala dan Rahardja, Pratama. 2008. Teori Ekonomi Makro. Edisi. Keempat. Jakarta: Lembaga Penerbit FE UI.

Martani, Dwi, Sylvia Veronika, Ratna Wardhani, Aria Farahmita, Erward Tanujaya, 2012, Akuntansi 
Keuangan Menengah Berbasis PSAK, Jakarta: Salemba Empat.

Masyud, Ali M., 2004. Asset Liability Management, Menyiasati Resiko Pasar dan Resio Operasional dalam Perbankan, PT. Elex Media Komputindo, Jakarta.

Moussa, Mohamed Aymen Ben. 2015. The Determinants of Bank Liquidity: Case of Tunisia. International Journal of Economics and Financial Issues, Vol. 5, No. 1, 2015, pp.249-259 ISSN: 2146-4138.

Mulyadi. 2008. Sistem Akuntansi, Cetakan Keempat, Jakarta: Salemba Empat..

2009. Akuntansi Biaya, Edisi ke-5, Salemba Empat, Jakarta.

Munawir. 2010. Analisa Laporan Keuangan Edisi keempat. Yogyakarta: Liberty.

Nachrowi, D, N, dan Hardius Usman. 2006. Pendekatan Populer dan Praktis Ekonometrika Untuk Analisis Ekonomi dan Keuangan, LP-FEUI, Jakarta.

Nikbakht, Maryam, Mahmood Bakhshi Nezhad dan Mohsen Azhdar. 2016. Investigating the effect of total capital ratio on bank liquidity of the banks listed in Tehran stock exchange. International Journal Of Humanities And Cultural Studies ISSN 2356-5926, Special Issue February 2016, http://www.ijhcs.com/index.php/ijhcs/index.

Nopirin. 2008. Pengantar Ilmu Ekonomi: Makro \& Mikro, Edisi ke-1. Yogyakarta: BPFE.

Ogilo, Fredrick dan Leonard Oscar Mugenyah. 2015. Determinants of Liquidity Risk of Commercial Banks in Kenya. The International Journal Of Business \& Management (ISSN 2321 -8916), www.theijbm.com, Vol 3 Issue 9 September, 2015.

Otoritas Jasa Keuangan Republik Indonesia. 2018. Statistik Perbankan Indonesia Vol. 16 Nomor 3 Februari 2018. Diakses dari https://www.ojk.go.id/, Tanggal 27 April 208.

Raeisi, Mohammad, Ali Haghighat, dan Jalil Khodaparast Shirazi. 2016. Bank Liquidity and its Effective Factors in Iran. International Journal of Educational Advancement Vol. 7 No.3, 2016, 315 -300 PISSN: 1744-6503 EISSN: 1744-6544.

Riyanto. 2008. Dasar-Dasar Pembelanjaan Perusahaan. Yogyakarta : BPFE.

Shamas, Ghanim, Zairani Zainol dan Zairy Zainol. 2018. The Impact of Bank's Determinants on Liquidity Risk: Evidence from Islamic Banks in Bahrain. Journal of Business \& Management (COES\&RJ-JBM), ISSN (E): 2306-7179 ISSN (P): 2306-8043, Publisher: Centre of Excellence for Scientific \& Research Journalism, COES\&RJ
LLC, Online Publication Date \& Issue: 1st January 2018, Vol.6, No.1, January 2018.

Sartono, Agus. 2010. Manajemen Keuangan Teori dan Aplikasi (4th ed.). Yogyakarta: BPFE.

Sawir, Agnes. 2012. Analisis Kinerja Keuangan dan Perencanaan Keuangan Perusahaan, Jakarta : Gramedia Pustaka Utama.

Sekaran, Uma. 2007. Research Methods for Business: Metodologi Penelitian untuk Bisnis. Edisi 4.Buku 1. Jakarta: Salemba Empat.

Singh, Anamika. 2016. An empirical analysis of macroeconomic and bank-specific factors affecting liquidity of Indian banks. Future Business Journal Volume 2 Issue 1, Juni 2016.

Soesastro, Hadi. 2005. Pemikiran dan Permasalahan Ekonomi di Indonesia, Jakarta: Erlangga.

Thamrin, Abdullah. 2012. Bank dan lembaga Keuangan. Depok: Rajagrafindo Persada.

Unit Pengembangan Fakultas Ekonomika, Universitas Diponegoro 2011. Modul EViews 6, Unit Pengembangan Fakultas Ekonomika, Universitas Diponegoro, Semarang.

Vodová, Pavla. 2011. Liquidity of Czech Commercial Banks and its Determinants. International Journal Of Mathematical Models And Methods In Applied Sciences, Issue 6, Volume 5, 2011.

Waemustafa, Waeibrorheem dan Suriani Sukri. 2016. Systematic and Unsystematic Risk Determinants of Liquidity Risk Between Islamic and Conventional Banks. International Journal of Economics and Financial Issues, ISSN: 21464138, Vol 6, Issue 4, 2016, 1321-1327. available at http: www.econjournals.com.

Warren, Reeve, dan Fess, 2008. Accounting (Pengantar Akuntansi) Buku Satu Edisi 2, Jakarta: Salemba Empat.

Yang, W. S., Loo, S. C., and Shamser. 2009. The Effect of Board Structure and Institutional Ownership Structure on Earnings Management. International Journal of Economics and Management, Vol.3, No.2: 332-353, ISSN: 1823-836X. 